\title{
The impact of the economic crisis on labor rights in Brazil $^{1}$
}

\author{
Mauri Antônio da Silva ${ }^{\mathbf{1}}$ \\ https://orcid.org/0000-0001-6162-0148 \\ ${ }^{1}$ Universidade Estadual do Tocantins, Curso de Graduação em Serviço Social, Palmas, TO, Brazil
}

The impact of the economic crisis on labor rights in Brazil

Abstract: This article carries out bibliographical research and analyzes the situation of the Brazilian workers in the context of the current national economic crisis, demonstrating an increase in unemployment rates after the approval of the 2017 labor reform by the National Congress. The economic analysis shows that the reform (considered here a counter-reform) was a measure of counter-trend planned by the capitalists to cope with the fall in profit rates. The trade unions' struggle was not able to avoid the regressive changes in the Brazilian labor legislation, which deteriorate the labor contracts and the living conditions of the working class.

Keywords: Labor rights. Economic crisis. Precariousness.

Submitted on September 27, 2018. Approved on November 20, 2018. Revised on April 15, 2019.

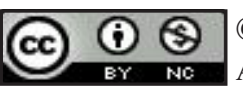

(C) The Author(s). 2019 Open Access This article is distributed under the terms of the Creative Commons Attribution-NonCommercial 4.0 International License (http://creativecommons.org/licenses/by-nc/4.0/), which permits use, distribution, and reproduction in any medium, since it's for non-commercial purposes, and provided you give appropriate credit to the original author(s) and the source, provide a link to the Creative Commons license, and indicate if changes were made. 


\section{Introduction}

The working classes in Brazil are currently suffering a challenging economic and political situation. The greatest economic crisis in the country's history (Cardoso, 2017), started in 2014, is trailing without a sign of a vigorous or even a moderate resumption of growth, maintaining high unemployment rates and increasing social insecurity.

After two years of deep recession, the Brazilian economy showed a slight recovery (growth of $1 \%$ ) in 2017, which still did not inspire optimism. Projections from financial market analysts based on the growth of $0.4 \%$ in the first quarter of 2018 indicated a growth of only 1.79\% in 2018 ("A Economia Continua," 2018; "A Previsão de Recuperação," 2018), but the result was lower than expected.

Data from the Instituto Brasileiro de Geografia e Estatística [Brazilian Institute of Geography and Statistics] (IBGE) show that the Brazilian economy grew by only $1.1 \%$ in 2018 in comparison to the previous year, reaching the same level of Gross Domestic Product (GDP) obtained in 2012 (Cardoso, 2019). Between the years 2015 and 2016, the GDP presented a negative variation of $-3.5 \%$ and $-3.6 \%$, respectively. In 2017, the growth of the Brazilian economy was only $1.1 \%$. In addition to the small growth in 2018 , there was poor performance in the fourth quarter of the year, with GDP growth only $0.1 \%$ in comparison to the previous quarter (Cardoso, 2019).

In this historical moment marked by the impacts of the global crisis of capitalism (started in 2008), the Brazilian federal government accelerates the adoption of legislation aimed at reducing worker's rights. It froze the budget for social investments, privileging financial capital in the federal government's budget, and proceeded with the subordinate and dependent insertion of Brazil into the world economy, hegemonized by the US imperialism.

The intention of the labor counter-reform in 2017 - which changed more than 100 articles of the country's labor legislation, called Consolidação das Leis do Trabalho [Consolidation of Labor Laws] (CLT) - was to reduce the value of the labor force and to increase the extraction of surplus value. In other words, it consisted of counter-measures adopted to recover the capitalist's profit rate, according to the argument based on the historical and dialectical materialism by Marx (1996) and Engels (1986).

This article aims to contribute to understanding the effects of the economic crisis on labor rights, analyzing the causal determinations of the labor counter-reform in Brazil. The study consists of a brief theoreticalbibliographic examination based on Marx's $(1983,1996)$ and Engels $(1986)$ works on the extraction of surplus value from workers, on studies on the expressions of the 2008 global crisis in Brazil, and documents of businesses, trade unions, and government agencies that show data, studies, and propositions on the subject.

The article is divided into two sections. The first, "Labor, Class Struggle and Profit Rates," presents Karl Marx's (1996) theory of value, demonstrating how the capitalist's exploitation of surplus value is the foundation of profit rates, which fall in times of economic crisis. The second section, "Fall of Profit Rate and the Attack on Labor Rights in Brazil," explains how capitalists respond to this fall, by reducing salaries, using legislative measures to suppress labor rights. My focus in this section is on the approval of the 2017 labor counter-reform and its effects on the Brazilian labor market.

\section{Labor, class struggle, and profit rates}

The human is in constant relationship with nature throughout life. They transform nature through work, producing material goods such as food, clothing, shoes, and dwellings. For Marx (1903 as cited in Lukács, 2012) work is the central category that conditions the ways the human being organizes social reproduction, which involves the relation between production and consumption (Lukács, 2012).

Through Marx's (1996) value theory, the hidden secret of the capitalist mode of production is revealed. Marx's studies show that this mode of production is supported by extracting the worker's surplus value, i.e., the appropriation of unpaid labor. Even when buying the worker's labor force paying all the value as a commodity in the market, the capitalist will always extract more value than the labor force costs. This surplus value is the source of the growing mass of accumulated capital in the hands of the capitalist classes (Engels, 1986).

Capitalism increasingly socializes production according to the development of labor's social productivity. However, capitalism implements, at the same time, a profound antagonism between, on one side, the holders of the means of production - who aim for the appropriation of surplus value (i.e., labor time that is the workers' surplus) - to obtain profit at the expense of misery and degradation of labor; and on the other side, the workers who sell their workforce, seeking to value their commodity as any other seller.

We see then, that, apart from extremely elastic bounds, the nature of the exchange of commodities itself imposes no limit to the working day, no limit to surplus labour. The capitalist maintains his rights as a 
purchaser when he tries to make the working day as long as possible, and to make, whenever possible, two working days out of one. On the other hand, the peculiar nature of the commodity sold implies a limit to its consumption by the purchaser, and the labourer maintains his right as seller when he wishes to reduce the working day to one of definite normal duration. There is here, therefore, an antinomy, right against right, both equally bearing the seal of the law of exchanges. Between equal rights force decides. Hence is it that in the history of capitalist production, the determination of what is a working day, presents itself as the result of a struggle, a struggle between collective capital, i.e., the class of capitalists, and collective labour, i.e., the working-class. (Marx, 2018, p. 141)

According to Ebert (2016, p. 356), the social mobilizations, in which workers rebelled against excessive working hours and painful conditions, were compensated by liberal-bourgeois-oriented governments with specific rights for workers, by establishing norms aimed at protecting the worker's labor conditions. Thus, the working class gradually obtained rights such as the eight-hour working day and the right to one-month annual leave.

However, as Marx (1983) pointed out in Book III of Capital, the essence of capitalist development includes the tendency for profit rates to fall. Observing that this fall provokes crises of the capital, the bourgeoisie produces counter-tendency measures to recover these rates. Some of these measures are the reduction of the value of salaries, and the increase in labor exploitation and unemployment, through the manipulation of economic policy and setbacks in labor rights (Silva, 2017).

The bourgeoisie continually seeks to maintain its hegemony over the systems of legal, political, and ideological mediation that affect the maintenance and reproduction of the capitalist economic base.

\section{Fall of profit rate and the attack on labor rights in Brazil}

Since the early 1990s, the Brazilian businesspeople have considered the change in labor laws a strategic goal. During that period, businesspeople from the state of São Paulo published a document entitled Livre para Crescer: Proposta para um Brasil Moderno [Free to Grow: Proposal for a Modern Brazil] (Federação das Indústrias do Estado de São Paulo, 1990), criticizing the social achievements of the 1988 Federal Constitution and advocating the modernization of labor laws. The publication exposed the liberalism and conservatism as the ideology supporting the changes advocated, reinforcing the role of the individual to the detriment of the collective, and defending the maintenance of the capitalist system. Based on this ideology, the state must move away from labor relations, which must be "freely" negotiated between workers and employers (Petras, 2000).

The fall in profit rate was observed by the Brazilian bourgeoisie as of 2011, when a period of deceleration of the Brazilian economy began, under the effects of the 2008 global crisis of capitalism (Harvey, 2011). This overproduction crisis increased unemployment and social inequalities, as well as stimulating a crusade by the capitalists against social rights and national sovereignty (Antunes \& Druck, 2015; Bruno \& Caffe, 2018; Singer, 2016).

In 2012, through a document entitled 101 Propostas para Modernização Trabalhista [101 Proposals for Labor Modernization] (Confederação Nacional da Indústria [CNI]), businesspeople presented to the National Congress numerous demands for changes in labor laws that suppress and reduce workers' rights gained in the class struggles since the nineteenth century.

Among the proposals presented to the National Congress was the possibility to take annual leave in parts rather than the whole month at a time, Sunday working for all workers, the suspension of Norma Regulamentadora [Regulatory Standard] (NR) No. 12, of the Ministry of Labor and Employment (Portaria No. 3.214, 1978) which protects workers operating machines regarding work accidents - unrestrained outsourcing, and the law authorizing collective negotiation to prevail over labor legislation. ${ }^{2}$

Other business organizations were advocating legislation changes of similar content. The Confederação Nacional da Agricultura [National Confederation of Agriculture] (CNA) proposed the redefinition of the legal concept of "work similar to slavery," removing from the concept the practice of excessive working hours and degrading working conditions. Also, since 2009 Confederação Nacional do Comércio [National Confederation of Commerce] (CNC) has proposed measures such as the implementation of negotiable working day and the reduction of restrictions on night working (Biavaschi \& Krein, 2016). ${ }^{3}$

Paving the way for these legislation changes, advocacy groups staged a coup against President Dilma Rousseff, who had been re-elected in 2014 with 54 million votes. The coup agenda was announced in the document Uma Ponte para o Futuro [A Bridge to the Future] published by the Partido do Movimento Democrático Brasileiro [Party of the Brazilian Democratic Movement] (PMDB) in 2015, and put into practice with the approval of President Rousseff's impeachment on August 31, 2016 (Jinkings, Doria, \& Cleto, 2016). 
The new government in office after the impeachment served to the Brazilian bourgeoisie, historically dependent and associated with the imperialism. It then started a process of dismantling social legislation and national sovereignty (Fernandes, 1975). Subsequently, the federal government and its parliamentary majority approved a 20-year budget freeze toward social spending. ${ }^{4}$ In addition, the government reaffirms its commitment to reduce labor costs by approving the unrestrained outsourcing law (Lei No. 13.429, 2017) allowing all the activities of the companies, including the core-activities, to be outsourced.

The recessive economic policy, led by Minister Henrique Meirelles, increased the reserve army of labor, which forces wage reduction. Data from the Pesquisa Nacional por Amostra de Domicilios [National Household Sample Survey] (PNAD) from IBGE published on the website of Agência Brasil de Comunicações (government's communication agency) reported $13.3 \%$ unemployment rate among the economically active population (Abdala, 2017). According to the agency, the unemployed population reached 13.8 million people in May 2017, remaining stable in comparison to February 2017 and growing 20.4\% in comparison to May 2016 (2.3 million more people). This was considered the highest unemployment rate for a quarter ended in May since the beginning of the PNAD in 2012 (Abdala, 2017).

At the end of 2016, the illegitimate government of President Michel Temer sent the labor reform proposal through Bill 6787/2016 (Projeto de Lei No. 6.787). The bill included the proposals of free negotiation ruling over the labor legislation, which challenges the progressive nature of Brazilian labor laws defined in art. 7 of the Brazilian Constitution that stipulates the rights of urban and rural workers, as well as others that aim to improve their social condition (Constituição Federal, 2000, p. 10).

Bill 6787/2016 (Projeto de Lei No. 6.787) amends the

\section{Changes promoted in the}

\section{working hours contribute to}

\section{making the work increasingly}

precarious, intense, sickening,

and subordinate to the dictates

of capital accumulation.
CLT, allowing the flexibilization of the constitutional and infraconstitutional legislation provided in the labor legislation, with the exception of the Normas Regulamentadoras (NRs) de Segurança e Medicina do Trabalho [Occupational Safety And Health Regulatory Standards]. ${ }^{5}$ The bill provides that the negotiations between unions representing employees and employers' associations overrule the provisions in law (as stated in the bills amendment to art. 611 of the CLT, which provides on Collective Labor Agreements (Projeto de Lei No. 6.787, 2016): Art. 611-A. The collective labor agreement has the force of law when it provides on: I- breaking down annual leave in up to three periods, with payment proportional to the break down agreed, so that one of the periods necessarily corresponds to a minimum of two uninterrupted weeks; II - to agree on the format of the working day, limited to two hundred and twenty monthly hours; III - participation in the company's profits and results, in order to include the payment of installments regarding this participation within the limits of the legally established periods to release the balance sheet, not less than two installments; IV - hours in itinere $;{ }^{6} \mathrm{~V}$ Breaks in working hours, respecting the minimum limit of thirty minutes; VI - ultrativity of the norm or the labor collective agreement of the workers' category; VII - adoption of the Programa de Seguro-Emprego [InsuranceEmployment Program] (PSE), which is provided by Law 13189 of November 19, 2015; VIII - Career and salary plan; IX - business regulation; X - compensatory time system, guaranteed the conversion of the hour that exceeds the normal working day with an increase of at least fifty percent; XI - remote work; XII - remuneration for productivity, including tips perceived by the employee; and XIII - working hours recording.

Bill 6787/2016 (Projeto de Lei No. 6.787) attempts to restrict the jurisdiction of the Labor Court. It states that it will analyze the legality of the results of collective labor agreements based on essential elements of the legal business, respecting the provisions established in the Civil Code (Lei No. 10.406, 2002). The bill instructs the Labor Court to act based on the principle of minimum intervention in the autonomy of the collective will (Projeto de Lei No. 6.787, 2016).

The bill also amends Law 6019/1974, extending the duration of the temporary work contract from 90 to 120 days, renewable for the same period. The workers can sell their labor force directly to the employer, with no need for intermediation by a company specialized in temporary work (Projeto de Lei No. 6.787, 2016).

As for part-time work, currently considered as such when it does not exceed 25 hours per week, the bill extends it, offering two possibilities. This type of contract can reach a maximum of 30 hours per week prohibiting additional weekly hours; or to a maximum of 26 hours, with the possibility of adding up to six additional hours a week, remunerated with a 50\% increase per hour-wage (Projeto de Lei No. 6.787, 2016).

The labor counter-reform establishes a deep flexibilization of labor legislation, establishing the prevalence of the agreement negotiated between employers and employees over what is provided for by law, a circumstance 
that had been pursued by the bourgeoisie since the beginning of the 1990s. Therefore, the precariousness of labor will be intensified through temporary and part-time work. The tendency is that there will be an increase in labor turnover, further aggravating the health problems resulting from the increased exploitation of working time available to the employer and the psychophysical exhaustion of workers. ${ }^{7}$

On April 26, 2017, the reform was approved by the Chamber of Deputies with the incorporation of dozens of amendments that radically changed the CLT. After that, the bill was appreciated by the Senate, where it was approved by the Comissão de Assuntos Econômicos [Committee on Economic Affairs] (CAE), rejected by the Comissão de Assuntos Sociais [Committee on Social Affairs] (CAS) (by a narrow difference of votes - 10 to 9) and approved by the Comissão de Assuntos Jurídicos [Committee on Legal Affairs] (CAJ) on June 28, 2017, by 16 votes to 9, with one abstention ("Senado Aprova Reforma," 2017).

The bill was subject to resistance from unions. Also, popular resistance was manifested through a nationwide strike on April 28, a march occupying Brasilia on May 24, and another nationwide strike on June 30, as well as meetings and demonstrations throughout the country. Regardless of the resistance, the counterreforms were approved by the Comissão de Constituição, Justiça e Cidadania [Committee on Constitution, Justice and Citizenship] (CCJ) of the Senate and forwarded to be voted in a plenary meeting. It was approved by the plenary on July 11, 2017, without amendments, and sent to Presidential sanction (Silva, 2018).

The central objective is a drastic reduction of the labor-value cost, with extreme precariousness of the Brazilian proletariat's working conditions, including exhausting, intense, intermittent working hours, with a clear reduction of the payment levels, in response to the capital needs of expanding gains based on the potentialization of human labor as a commodity (Coutinho, 2017).

According to Coutinho (2017), President Temer's labor reform profoundly changed the CLT and represented a return to the nineteenth century. The CLT had, in 1943, 921 articles. The legislation passed during President Temer's mandate presented 201 proposals that represented direct attacks on the workers' rights. In total, 120 articles were amended in what can be considered a "massacre" of the previous legislation, as observed regarding working hours (Maior \& Severo, 2017).

Regarding changes related to working hours, Coutinho (2017) poins out: 1) no computation of part of the time the employee remains in the employer's premises (art. 4, ๆ 2); 2) end of hours in itinere (art. 58, ๆ 2); 3) increase of the part-time contract from 25 to 36 hours per week (art. 58-A); 4) authorization for overtime in parttime contracts (art. 58, $\mid 5$ ); 5) compensation of the extra working hours beyond the weekly limit (art. 58, \5); 6) hiring overtime by individual labor agreement (art. 59); 7) expansion of the so-called "comp time" to also authorize it by individual labor agreement (art. 58, $\$ 5) ; 8$ ) compensation of extra working hours by individual, tacit or written labor agreement (art. 58, $\mid 6)$; 9) establishment of working hours in the format 12 hours per 36 thirty-six hours of rest, by individual labor agreement (art. 59-A), without weekly paid rest or holiday leave (art. 59-A) and with simple indemnification of the break in working hours (art. 59-A, sole paragraph); 10) even if usual overtime is performed in addition to the extension and compensation agreement, or the establishment of the comp time system, these methods of legitimizing non-payment of overtime are intact (art. 59-B); 11) exemption from prior authorization for the provision of the $12 \mathrm{~h}$ x $36 \mathrm{~h}$ working hours (art. 60, sole paragraph); 12) the excess of working hours demanded independently of provision in collective norm (art. 61, ๆ 1); 13) teleworkers are not entitled to receive overtime (art. 62, $\S$ III); 14) encouragement not to grant breaks in working hours, using the system of imdemnification (art. 71, 14 ); 15) even having to be regularly in the company's headquarters the remote worker is not entitled to be payed overtime (art. 75-B); 16) creation of the intermittent contract (art. 443), when the employee will work according to the interests of the company, receiving only for the hours worked, allowing the payment of a salary lower than the legal minimum, including the so-called "zero wage," without computing the work hours in which the worker was available to the employer, with all salary and severance payments severely mitigated (art. 443, ๆ3, art. 452-A, art. 452-A, ๆף 1-6); 17) prevalence of the labor agreements over the legislation on working hours, annual compensatory time system, breaks in working hours limited to 30 minutes, remote work, on-call and intermittent work regime, working day recording, exchange of the day of holiday and extension of the working hours in unhealthy environments, without prior authorization from the competent authorities of the Ministry of Labor (art. 611-A, §§ I-III, VIII, X-XI, XIII).

Changes promoted in the working hours contribute to making the work increasingly precarious, intense, sickening, and subordinate to the dictates of capital accumulation.

Modifications that are prejudicial to the health of the worker were legalized in art. $611-\mathrm{B}, \S$ XVIII of the CLT. The article states that it is illegal to suppress or reduce the rights that are part of the norms of health, hygiene, and safety at work provided for by law or by norms of the Ministry of Labor (Lei No. 13.429, 2017). However, at the same time, in the sole paragraph of the same article, the law says that changes concerning rules on working hours and intervals are not considered to be health, hygiene, and safety standards for work for the purposes of this article (Lei No. 13.429, 2017). This change goes against the right to health as a fundamen- 
tal right of the person (Dallari, 2004), who depends on fair working conditions, which include the management of working time - schedules, rhythms, and shifts that are reflected in health (Berlinguer, 1983).

During the appreciation of the bill, technical report from the Office of the Labor Prosecutor General (Ministério Público do Trabalho, Secretaria de Relações Institucionais, 2017) highlighted unconstitutionality at various points of the labor reform. Among them, the Prosecutor General before the Labor Court, Ronaldo Fleury, emphasized the distortion of the employment regime; broad and unrestricted outsourcing; flexibilization of the working hours with limits higher than the current ones; violation of the fundamental right to the minimum wage, to remuneration for work and equitable salary ("Nova Nota Técnica," 2017). After the new legislation was promulgated, eighteen Ações Diretas de Inconstitucionalidade [Direct Unconstitutionality Actions] (ADINs) have been before the Supremo Tribunal Federal [Federal Supreme Court] (STF). In addition to these actions, 85 amendments were taken through Medida Provisória [Provisional Measure] (MP) 808/2017 (Medida Provisória No. 808). Also, the MP 808/2017 received 967 amendments (historical record), thus increasing the legal labyrinth of the labor legislation (Maior, 2018). ${ }^{8}$

The reform was presented to society as a way to reactivate the economy, formalize jobs, and expand rights without removing any (Lei No. 13.467, 2017). In practice, however, it increased the impoverishment of the poorest population, by reducing their wage while increasing the precariousness and exploitation of workers. The workers' reaction has been manifested through strikes ("Balanço das Greves," 2017). ${ }^{9}$

The Departamento Intersindical de Estatística e Estudos Socioeconômicos [Inter-Union Department of Statistics and Socioeconomic Studies] (DIEESE) issued a warning related to dismissals as a consequence of the new legislation, which was confirmed by data from the Cadastro Geral de Empregados e Desempregados [National Register of Employed and Unemployed Persons] (Caged), released by the Ministry of Labor. The register showed 82,984 cases of labor contracts' termination by agreement between November 2017 and June 2018 (“Aumenta Número," 2018). The labor reform allowed an agreement between employer and employee to terminate labor contracts. In this case, the worker receives half of the notice pay, and can withdraw $80 \%$ of the Fundo de Garantia do Tempo de Serviço [Length of Service Guarantee Fund] (FGTS). In addition, the employee receives only $20 \%$ (instead of the $40 \%$ due when the employer is the party who terminates the labor contract) of the total amount in their FGTS account, to be paid by the employer in the occasion of the contract's termination (Ministério do Trabalho, n.d.).

The July 2018 edition of the Boletim Emprego em Pauta (DIEESE's periodic report on employment) demonstrated the worsening of working conditions, by analyzing the PNAD's data from IBGE ("Trabalho por Conta Própria," 2018). After the economic crisis, the number of self-employed workers increased. By 2017, about 23 million workers were in this condition, of which 5 million had become self-employed for less than two years ("Trabalho por Conta Própria," 2018). Brazilians in self-employment after the crisis perceive 33\% lower income than those self-employed for the longest time, in addition to being less protected by social security and less qualified workers ("Trabalho por Conta Própria," 2018).

Data from PNAD shows that, among those who were self-employed for less than two years, $77 \%$ did not have a Cadastro Nacional da Pessoa Jurídica [National Register of Legal Entities] (CNPJ) or contribute to Social Security. This percentage is higher than the figures for those in self-employment for the longest time. Also, among the recently self-employed less than $9 \%$ had CNPJ and contributed to Social Security (which is the situation of the population registered as Microempreendedor Individual [Individual Micro-Entrepreneur] (MEI), for example). Finally, about $10 \%$ of recently self-employed contributed to the Social Security, even though they did not have CNPJ (a condition that guarantees at least some social security benefits, such as accident insurance, maternity/paternity leave). However, this figure is still lower than the ones observed among the population self-employed for the longest time (19\%) (“Trabalho por Conta Própria," 2018).

The International Labor Organization (ILO), in a report of its Committee of Experts ("Comitê da OIT," 2018), condemned some aspects of the reform that are detrimental to the progressiveness of labor rights, requesting the revision of some items and detailed response from the Brazilian government. One of the items cited by the experts regards the prevalence of collective labor agreements over the legislation, provided by art. 611 of the CLT.

This article of the legislation is precisely the opposite of ILO Conventions 98 and 154, which is to promote collective labor agreement with the idea that agreements should establish more favorable working conditions than those laid down by law ("Comitê da OIT," 2018).

Because of the non-observance to Convention 98 (which deals with the right of collective bargaining, and negotiation through trade union organizations), Brazil was included in the list of the 24 countries that violate the international labor standards. The country had to explain to the ILO committee of experts, in November 2018, that it was not violating Convention 98 (Melim, 2018). 


\section{Conclusion}

Within the capitalist crises that have been deepening since the 1970s, both the declining trend of the profit rates and the destructive expansionist logic of capital stand out. Those years witnessed the start of the erosion of the social regulation system, in place since the post-war period in many developed capitalist countries, especially in continental Europe. In this period, a worldwide neoliberal attack has been observed, as a countertendency opposing the social system. In this context, privatization of public assets, production restructuring, and the deregulation of labor rights were accelerated in order to offer the capital the necessary instruments to try to restore the previous expansion levels (Antunes, 1999, p. 31).

With the worsening of the 2008 world capitalist crisis that struck Brazil more severely in 2011, the Brazilian bourgeoisie led by the industrialists renewed their attacks against labor rights. The capitalists, aided by their organic intellectuals, devised their legislative, political, and economic strategies to reduce labor costs, i.e., variable capital, to increase their appropriation of surplus labor and recover their profit rates.

The Brazilian bourgeoisie has built the arguments against labor rights since the beginning of the 1990s, in opposition to the social advances of the 1988 Brazilian Constitution, conquered by the pressure of social movements on the 1987-1988 National Constituent Assembly.

The liberal ideology that underlies the modernization of labor pursued by the businesspeople advocates the free market and negotiation between workers and employers, without the regulation of the State. Business organizations always pressure the legislative, executive, and judiciary to implement their proposals.

Following the coup d'état of 2016, the federal government aligned with the businesses' agenda and proposed a labor counter-reform, which was expanded and approved by liberals and conservative deputies and senators in the Brazilian National Congress, dismantling the 1943's labor legislation (CLT), created based on the workers' struggles for social rights.

The objective announced by the advocates of the counter-reform intended to obtain the acceptance of society to the flexibilization of the labor rights, through the free negotiation between workers and employers. The rationale was that this format of the contract would reactivate the economy and create jobs. This study showed that, contrary to the official and class-based discourses nourished by the liberal economic thinking, what happened was the increase of precarious work, unemployment, social inequalities, and the persistence of the crisis revealed by the Brazilian low economic growth of $1.1 \%$ in 2018.

\section{References}

Abdala, V. (2017, June 30). Taxa de desemprego no país se mantém em 13,3\%, diz IBGE. Agência Brasil. Retrieved from http:// agenciabrasil.ebc.com.br/

Antunes, R. (1999). Os sentidos do trabalho: Ensaio sobre a afirmação e a negação do trabalho. São Paulo, Brazil: Boitempo.

Antunes, R., \& Druck, G. (2015). A terceirização sem limites: a precarização do trabalho como regra. O Social em Questão, 18(34), $19-40$. Atrasos salariais, férias e $13^{\circ}$ salário respondem por quase metade das paralisações no primeiro trimestre. (2018, June/July). Cadernos de Negociação. Retrieved from https://www.cnts.org.br/wp-content/uploads/2018/06/cadernoNegociacao8.pdf

Aumenta número de demissões por comum acordo entre trabalhador e empresa. (2018, July/August). Cadernos de Negociação. Retrieved from https://www.cnts.org.br/wp-content/uploads/2018/08/cadernoNegociacao9.pdf

Balanço das greves de 2017. (2018). Estudos e Pesquisas, 2018(87). Retrieved from https://www.dieese.org.br/sitio/ buscaDirigida?itemBusca=\&comboBuscaDirigida $=$ TIPO $\% 7 C 1276721334968$

Balanço das greves de 2016. (2017). Estudos e Pesquisas, 2017(84). Retrieved from https://www.dieese.org.br/sitio/ buscaDirigida?itemBusca=\&comboBuscaDirigida=TIPO $\% 7 \mathrm{C} 1276721334968$

Berlinguer, G. (1983). Medicina e politica (2nd ed.). São Paulo, Brazil: CEBES: Hucitec.

Biavaschi, M. B. (2016). O impeachment e os direitos sociais do trabalhador: caminhos de uma ordem mais desigual. In C. Proner, G. Cittadino, M. Tenenbaum, \& W. Ramos Filho (Orgs.), A resistência ao golpe de 2016 (pp. 267-269). Bauru, Brazil: Canal 6.

Biavaschi, M. B., \& Krein, J. D. (2016). O retorno do passado II: O canto da sereia e os desencantos da nova ordem. In G. T. Ramos, H. C. Melo Filho, J. E. Loguercio, \& W. Ramos Filho, (Orgs.), A classe trabalhadora e a resistência ao golpe de 2016 (pp. 279-284). Bauru, Brazil: Canal 6.

Bruno, M., \& Caffe, R. (2016). Determinantes das taxas de lucro e de acumulação no Brasil: os fatores estruturais da deterioração conjuntural de 2014-2015. Proceedings of the Seminário sobre a economia mineira, 17. Retrieved from https://diamantina.cedeplar.ufmg.br/portal/publicacoes/ Cardoso, J. A. de L. (2017, October 24). Cresce a importância das organizações sindicais. Retrieved from http://www.fecesc.org.br/ cresce-importancia-das-organizacoes-sindicais

Cardoso, J. A. de L. (2019, March 7). O fracasso da política econômica do golpe e a tentativa de esmagar as organizações sindicais. Retrieved from http://www.sindaspisc.org.br/noticias.php?cnoticia=2451 
CNC e Sebrae propõem 138 ações estratégicas para comércio e serviços. (2009, December 10). Retrieved from http://empreendedor.com.br/ noticia/cnc-e-sebrae-propoem-138-acoes-estrategicas-para-comercio-e-servicos

Comitê da OIT quer que governo reveja itens da nova lei trabalhista. (2018, February 9). Retrieved from http://www.redebrasilatual.com.br/ trabalho/2018/02/comite-da-oit-quer-que-governo-reveja-itens-da-nova-lei-trabalhista

Confederação Nacional da Indústria. (2012). 101 propostas para modernização trabalhista. Retrieved from http:// www.portaldaindustria.com.br/publicacoes/2013/2/101-propostas-para-modernizacao-trabalhista/

Confederação Nacional da Indústria. (2013). Mapa estratégico da indústria 2013-2022 (2nd ed.). Retrieved from https://bucket-gw-cnistatic-cms-si.s3.amazonaws.com/media/filer_public/19/38/19386bd6-37be-4b51-95ef-564bd3a87785/20130927152120322966i.pdf Confederação Nacional da Indústria. (2016a). Agenda legislativa da indústria 2016. Retrieved from http://www.sistemaindustria.org.br/ publicacao/agenda_legislativa2016/HTML/files/assets/common/downloads/publication.pdf

Confederação Nacional da Indústria. (2016b). 119 propostas para a competitividade com impacto fiscal nulo. Retrieved from http:// www.portaldaindustria.com.br/publicacoes/2016/7/119-propostas-para-competitividade-com-impacto-fiscal-nulo/

Confederação Nacional da Indústria. (2017, March). Agenda para o Brasil sair da crise 2016-2018: Evolução após um ano [PowerPoint presentation]. Retrieved from https://bucket-gw-cni-static-cms-si.s3.amazonaws.com/media/filer_public/59/da/59da2e37-b6c9-4b72a2c7-7f80f1caea50/agenda_para_o_brasil_sair_da_crise_2016-2018_apos_um_ano.pdf

Constituição Federal [Constitution]. São Paulo, Brazil: Revista dos Tribunais, 2000.

Coutinho, G. (2017, July 10). "Reforma” trabalhista de Temer retrocede ao século 19. Retrieved from http://www.diap.org.br/index.php/ noticias/agencia-diap/27347-reforma-trabalhista-de-temer-retrocede-ao-seculo-19

Dallari, D. de A. (2004). Direitos humanos e cidadania. São Paulo, Brazil: Moderna.

Ebert, P. R. L. (2016). O direito do trabalho no século XXI e as alternativas a reforma trabalhista precarizante nos planos doméstico e internacional. In G. T. Ramos, H. C. Melo Filho, J. E. Loguercio, \& W. Ramos Filho (Orgs.), A classe trabalhadora e a resistência ao golpe de 2016 (pp. 355-360). Bauru, Brazil: Canal 6.

A economia continua se movendo lentamente, mas crescem as ameaças de novo recuo. (2018). Boletim de Conjuntura, 2018(15). Retrieved from https://www.dieese.org.br/sitio/buscaDirigida?itemBusca=\&comboBuscaDirigida=TIPO\%7C1425406773980

Emenda Constitucional No. 95, de 15 de Dezembro de 2016, Diário Oficial da União [D.O.U] de 15.12.2016. Retrieved from http:// www.planalto.gov.br/ccivil_03/constituicao/emendas/emc/emc95.htm

Engels, F. (1986). Do socialismo utópico ao socialismo cientifico (R. Goldkorn, Trans., 8th ed.). São Paulo, Brazil: Global.

Federação das Indústrias do Estado de São Paulo. (1990). Livre para crescer: Proposta para um Brasil moderno. São Paulo, Brazil: Cultura.

Fernandes, F. (1975). Capitalismo dependente e classes sociais na América Latina (2nd ed.). Rio de Janeiro, Brazil: Zahar. Harvey, D. (2011). O enigma do capital: E as crises do capitalismo (J. A. Peschanski, Trans.). São Paulo, Brazil: Boitempo.

Instrução Normativa No. 129, de 11 de janeiro de 2017, Diário Oficial da União [D.O.U] de 12.1.2017. Retrieved from http:// pesquisa.in.gov.br/imprensa/jsp/visualiza/index.jsp?data=12/01/2017\&jornal=01\&pagina $=36$

Jinkings I., Doria, K., \& Cleto, M. (Orgs.). (2016). Por que gritamos golpe? Para entender o impeachment e a crise política no Brasil. São Paulo, Brazil: Boitempo.

Lei No. 13.467, de 13 de julho de 2017, Diário Oficial da União [D.O.U] de 17.7.2017. Retrieved from http://www.planalto.gov.br/ ccivil_03/_ato2015-2018/2017/lei/L13467.htm

Lei No. 13.429, de 31 de março de 2017, Diário Oficial da União [D.O.U] de 31.3.2017. Retrieved from http://www.planalto.gov.br/ ccivil_03/_Ato2015-2018/2017/Lei/L13429.htm

Lei No. 10.406, de 10 de janeiro de 2002, Diário Oficial da União [D.O.U] de 11.1.2002. Retrieved from http://www.planalto.gov.br/ CCIVIL_03/LEIS/2002/L10406.htm

Lukács, G. (2012). Para uma ontologia do ser social I. São Paulo, Brazil: Boitempo.

Maior, J. S. (2018, February 2). A "reforma" trabalhista já era - Parte VI: o labirinto jurídico [Blog post]. Retrieved from https:// www.jorgesoutomaior.com/blog/a-reforma-trabalhista-ja-era-parte-vi-o-labirinto-juridico

Maior, J. S., \& Severo, V. (2017, May 8). Os 201 ataques da "reforma" aos trabalhadores [Blog post]. Retrieved from http:// www.jorgesoutomaior.com/blog/os-201-ataques-da-reforma-aos-trabalhadores

Marx, K. (1983). O capital: Crítica da economia política: Livro III [Capital: Critique of political economy: Book III] (R. Sant'Anna, Trans., 5th ed., Vol. 5). Rio de Janeiro, Brazil: Difel.

Marx, K. (1996). O capital: Crítica da economia política: Livro I [Capital: Critique of political economy: Book I (R. Sant'Anna, Trans., 15th ed., Vols. 1-2). Rio de Janeiro, Brazil: Bertrand Brasil.

Marx, K. (2018). The process of capitalist production (S. Moore \& E. Aveling, Trans.). Retrieved from http://books.google.com/books Medida Provisória No. 808, de 14 de novembro de 2017, Diário Oficial da União [D.O.U] de 14.11.2017. Retrieved from http:// www.planalto.gov.br/ccivil_03/_Ato2015-2018/2017/Mpv/mpv808.htm

Melim, T. (2018, June 7). Temer é derrotado na OIT e será obrigado a explicar reforma trabalhista nefasta. Retrieved from https:// www.cut.org.br/noticias/temer-e-derrotado-na-oit-e-sera-obrigado-a-explicar-reforma-trabalhista-nefasta-8e51

Ministério do Trabalho. (n.d.). Modernização trabalhista: Conheça as principais mudanças. Retrieved from http://www.secom.gov.br/ atuacao/publicidade/textos/Cartilha_LeiTrabalhistas_150x210_24pgs003.pdf 
Ministério Público do Trabalho, Secretaria de Relações Institucionais. (2017). Nota Técnica $n^{\circ} 08$, de 26 de junho de 2017. Retrieved from http://portal.mpt.mp.br/wps/wcm/connect/portal_mpt/ce4b9848-f7e4-4737-8d81-6b3c6470e4ad/ Nota\%20t\%C3\%A9cnica\%20n\%C2\%BA\%208.2017.pdf?MOD=AJPERES

Nova nota técnica do MPT aponta inconstitucionalidades da reforma trabalhista. (2017, June 27). Retrieved from https:// www.cartamaior.com.br/?/Editoria/Estado-Democratico-de-Direito/Nova-nota-tecnica-do-MPT-aponta-inconstitucionalidades-dareforma-trabalhista-/40/38335

Oxfam Brasil. (2017). A distância que nos une: Um retrato das desigualdades brasileiras. Retrieved from https://www.oxfam.org.br/ sites/default/files/arquivos/relatorio_a_distancia_que_nos_une.pdf

Petras, J. (2000). Hegemonia dos Estados Unidos no novo milênio. Petrópolis, Brazil: Vozes.

Portaria No. 3.214, de 8 de junho de 1978, Diário Oficial da União [D.O.U] de 6.7.1978. Retrieved from http://www.trabalho.gov.br/ images//Documentos/SST/NR/NR12/NR-12.pdf

A previsão de recuperação não inspira otimismo. (2018). Boletim de Conjuntura, 2018(13). Retrieved from https://www.dieese.org.br/ sitio/buscaDirigida?itemBusca $=\&$ comboBuscaDirigida $=$ TIPO $\% 7 C 1425406773980$

Projeto de Lei No. 6.787, de 2016, Diário da Câmara dos Deputados [D.C.] de 4.2.2017 Retrieved from http://imagem.camara.gov.br/ Imagem/d/pdf/DCD0020170204000170000.PDF\#page=17

Seligmann-Silva, E. (2011). Trabalho e desgaste mental: O direito de ser dono de si mesmo. São Paulo, Brazil: Cortez.

Senado aprova reforma trabalhista-sindical; vai à sanção. (2017, July 11). Retrieved from http://www.diap.org.br/index.php/noticias/ agencia-diap/27354-senado-aprova-reforma-trabalhista-sindical-vai-a-sancao

Silva, M. A. da. (2017). Consequências da crise do capital sobre a classe trabalhadora brasileira (1990-2016) (Doctoral thesis, Federal University of Santa Catarina, Florianópolis, Brazil). Retrieved from https://repositorio.ufsc.br/handle/123456789/182596

Silva, M. A. da. (2018, July). Brasil: a resistência dos trabalhadores à "Reforma” Trabalhista. In A. Galvão, S. Cavalcante, \& S. Arias (Chair), Os protestos contra a crise econômica, política e ideológica. Symposium conducted at Fourth International Conference Greves e Conflitos Sociais, São Paulo, Brazil.

Singer, A. (2016). A (falta) de base política para o ensaio desenvolvimentista. In A. Singer \& I. Loureiro (Orgs.), As contradições do lulismo: A que ponto chegamos? (pp. 21-54). São Paulo, Brazil: Boitempo.

Trabalho por conta própria cresce na crise, mas em piores condições. (2018, July). Boletim Emprego em Pauta. Retrieved from https:/ /www.dieese.org.br/boletimempregoempauta/2018/boletimEmpregoEmPauta8.html

\section{Notas}

1 This article updates and expands part of the reflections explained in the doctoral thesis in Social Work entitled Consequencias da Crise do Capital sobre a Classe Trabalhadora Brasileira (1990-2016) [Consequences of the Crisis of Capital on the Brazilian Working Class (1990-2016)], defended in the Graduate Program in Social Work of the Federal University of Santa Catarina, in February 2017.

2 The documents Agenda Legislativa da Indústria 2016 [2016 Industry Legislative Agenda] (CNI, 2016a) and 119 Propostas para a Competitividade com Impacto Fiscal Nulo [119 Proposals for Competitiveness with Null Fiscal Impact] (CNI, 2016b) reinforced the businesses demands for the flexibilization of labor rights. The document Agenda para o Brasil Sair da Crise 2016-2018: Evolução após Um Ano [Agenda for Brazil to Overcome the Crisis 2016-2018: Evolution after One Year], also published by CNI (2017), confirms these proposals. The document presents 36 measures that the business sector consider essential to resume economic growth. In this document, the CNI(2017) advocates measures of fiscal adjustment, reforms in labor, social security, and tax legislation, expansion of concessions in infrastructure, free trade agreements to expand foreign trade, better credit conditions for companies, and suspension of new ancillary obligations which, according to the entity, increase cost and bureaucracy for companies.

3 For more details on the subject see CNC e Sebrae propõem 138 ações estratégicas para comérico e serviço [CNC and Sebrae propose 138 strategic actions for trade and services] (“CNC e Sebrae,” 2009).

4 Constitutional Amendment 95, known as the Proposta de Emenda à Constituição (PEC) do Novo Regime Fiscal [Bill of Constitutional Amendment of the New Fiscal Regime], approved by the National Congress and promulgated on December 15, 2016 (Emenda Constitucional No. 95). In practice, it limits social spending for twenty years, making it impossible to implement the Plano Nacional de Educação [National Education Plan] (PNE), the expansion of the Sistema Único de Saúde [Unified Health System] (SUS) and the Sistema Único da Assistência Social [Unified System of Social Assistance] (SUAS), among other social programs necessary for the fight against social inequalities in the country (Oxfam Brasil, 2018).

5 Since the Ministry of Labor draws up these specific NRs, there was no need for the capitalists to include amendments in the collective agreements as part of this bill. In a capitalist state, it is easier for the businesspeople, through their representatives in the leadership of the Ministry of Labor to change the NRs with validity for all the workers nationwide, such as in the case of NR-12, that was changed during the period Minister Ronaldo Nogueira was in office. As the CNI (2017) informs in its document Agenda para o Brasil Sair da Crise 2016-2018: Evolução após Um Ano [Agenda for Brazil to Overcome the Crisis 2016-2018: Evolution after One Year], on January 12, 2017, the Ministry of Labor published Normative Instruction 129/2017 (Instrução Normativa No. 129) establishing special procedures to monitor the application of NR-12, extending to 12 months the period for businesses to correct irregularities identified in inspections. 
6 Time spent by the employee to commute.

7 On the relationship between precarious work, work rhythm, and illnesses see Seligmann-Silva (2011).

8 Some controversial or admittedly unconstitutional themes of the labor reform were approved in the Federal Senate, so that the proposal did not return to the Chamber of Deputies. The Federal Government has committed to the senators to send a MP soon after the promulgation of the reform. MP 808/2017 (Medida Provisória No. 808) alters seventeen articles of the labor reform, including intermittent and autonomous work, providing on representation of workers in the workplace, working conditions for pregnant and lactating women, and a workday of $12 \times 36$ hours. MP 808/2017 expired because Congress did not vote it within the legal deadline. The jurist Souto Maior argues that the expiration of the MP leaves no argument legitimating the legislative process that approved Law 13467/2017, considering, above all, that the expired MP 808 exposed some of the legislation various problems. About this issue, see Maior (2018).

9 The DIEESE(“Balanço das Greves," 2017) registers an increase in the number of strikes in 2012, which continued in 2016, when there were 2,093 strikes, of which 1,100 in the public sector, 986 in the private sector, and 7 in joint action of the public and private sectors. In 2016, about 81\% of strikes had among the demands items related to promoting labor rights; and more than half (56\%) denounced noncompliance with rights. Propositional claims (new rights) were present in $34 \%$ of the strikes. In a context of rising unemployment and reduced wage gains, union strikes are increasingly focusing on immediate and urgent issues, i.e., the fight against layoffs and salary arrears. Further and more detailed studies on these mobilizations are needed, considering that the number of strikes in 2014 and 2015 is still not yet computed. According to DIEESE("Balanço das Greves," 2017), the register of strikes in the Sistema de Acompanhamento de Greves [Strike Monitoring System] (SAG-DIEESE) for 2014 and 2015 is still not completed, due to the high number of occurrences. It is important to observe that this number of strikes offer evidence against the discourse of working class' passivity. In the first quarter of 2018, the SAG-DIEESE registered 408 strikes, most of them presenting a defensive nature, as a trend in the context of high unemployment and turnover rates that followed the implementation of the labor counter-reform. According to DIEESE (“Atrasos Salariais," 2018), the majority (53\%) of the strikes were in the public sector, with emphasis on the workers of the municipal education (58 strikes) and health (30) systems. Among the strikes in the private sector (46\%), health workers working in hospitals and social organizations ( 37 strikes) and those in urban collective transportation buses stand out ( 32 strikes). About $85 \%$ of these demonstrations had at least one defensive item in the list of demands. Failure to comply with the rights guaranteed by law or labor agreement resulted in $58 \%$ of the strikes. Arrears of salaries, paid annual leave, bonus salaries (called décimo terceiro salário in Brazil), accounted for $44 \%$ of the strikes held until the middle of March. In 2017, the worsening of the labor market reduced workers' fighting capacity, as the number of strikes registered dropped to 1,566, which means a 25\% decrease compared to the 2,000 annual strikes registered in 2016 ("Balanço das Greves," 2018).

\section{Mauri Antonio da Silva}

mauri.silva19@gmail.com

Doctor of Social Work from the Graduate Program in Social Work of the Universidade Federal de Santa Catarina (UFSC)

Temporary Lecturer at the Social Work Undergraduate Program of the Universidade Estadual do Tocantins (UNITINS)

\section{UNITINS}

Quadra 108 Sul Alameda 11, Lote 03 - Plano Diretor Sul

Palmas - Tocantins - Brazil

CEP: $77.020-122$

\section{Funding}

Not applicable.

\section{Authors' contributions}

Not applicable.

Ethics approval and consent to participate

Not applicable.

\author{
Consent for publication \\ Not applicable.
}

\section{Competing interests}

There are no competing interests. 